\title{
Difference Effect Between Gargling with Green Tea Water and Cinnamon Decoction Against Halitosis
}

\author{
Poetry Oktanauli ${ }^{1}$, Pinka Taher ${ }^{2}$, Nadia Safira Prayogi ${ }^{3}$ and Farah Andita Timur ${ }^{4}$ \\ \{ poetry@dsn.moestopo.ac.id ${ }^{1}$, pinka.taher@dsn.moestopo.ac.id ${ }^{2}$, nadiaprayogi@gmail.com ${ }^{3}$, \\ farahanditatimur@yahoo.com $\left.{ }^{4}\right\}$ \\ ${ }^{1,2}$ Department of Oral Biology, Faculty of Dentistry, Universitas Prof. Dr. Moestopo (Beragama), \\ Jakarta, Indonesia. \\ ${ }^{3,4}$ Clinical Programme, Faculty of Dentistry, Universitas Prof. Dr. Moestopo (Beragama), Jakarta, \\ Indonesia.
}

\begin{abstract}
Halitosis is an unpleasant odor. The main cause of halitosis is Volatile Sulfur Compounds (VSC). There is an easy way to overcome halitosis in everyday life. Therefore, this paper is aimed to give information about what is the differences effect between gargling with green tea water and cinnamon decoction against halitosis. The results showed that the average halitosis score in green tea was higher than cinnamon. Green tea is a type of tea that has a very high catechins content. Catechins are compounds that can inhibit the growth of bacteria that cause halitosis. Benefits possessed by cinnamon is derived from the chemical compounds contained in cinnamon essential oil. Eugenol is the main content in cinnamon that has antibacterial properties, so it can reduce the score of halitosis. The writer concludes that gargling with cinnamon decoction, proved to be more effective in lowering the halitosis score compared to green tea.
\end{abstract}

Keywords: Green tea water, Cinnamon decoction, Halitosis.

\section{Introduction}

Halitosis is an unpleasant odor [1]. The main causes of halitosis are Volatile Sulfur Compounds (VSC), which are produced by anaerobic microorganisms [2]. There is an easy way to overcome halitosis in everyday life by gargling. In this study, subjects will be rinsed using green tea water and cinnamon decoction. Green tea can be used to reduce halitosis. Green tea is easy to find, safe for consumption, and the price is relatively cheap. Green tea has several chemical constituents [3]. Cinnamon has been used extensively in Indonesia as a flavor. Some studies suggest that cinnamon has been used to treat toothache and overcome halitosis [4]. Therefore, this paper is aimed to give information about what is the differences effect between gargling with green tea water and cinnamon decoction against halitosis. This research was conducted at Pesantren Khusus Yatim As-Syafi'iyah. Through the results of this study, it is expected to be useful for the community, so that they can pay more attention to the health and hygiene of the oral cavity. 


\section{Method}

This study is an analytic research with cross sectional research design. This study was done in January 2018, with pre and post test. The population of the study were 30 subjects Santriwan/Santriwati at Pesantren Khusus Yatim As-Syafi'iyah, taken by quota sampling. Halimeter has been used as a measuring instrument in this study. Analysis was done by bivariately, with Wilcoxon statistical data analysis.

\section{Result}

The result of this study were:

Table 1. Frequency of halitosis scores before treatment (with green tea).

\begin{tabular}{clcr}
\hline Scores & Halitosis & Frequency & \% \\
\hline 0 & No Odor & 0 & 0 \\
1 & Slight Odor & 0 & 0 \\
2 & Moderate Odor & 4 & 13 \\
3 & Heavy Odor & 10 & 33 \\
4 & Strong Odor & 11 & 37 \\
5 & Intense Odor & 5 & 17 \\
\hline Total & & $\mathbf{3 0}$ & $\mathbf{1 0 0}$
\end{tabular}

Table 2. Frequency of halitosis scores after treatment (with green tea).

\begin{tabular}{clcr}
\hline Scores & Halitosis & Frequency & \% \\
\hline 0 & No Odor & 0 & 0 \\
1 & Slight Odor & 4 & 13 \\
2 & Moderate Odor & 13 & 44 \\
3 & Heavy Odor & 10 & 33 \\
4 & Strong Odor & 3 & 10 \\
5 & Intense Odor & 0 & 0 \\
\hline Total & & $\mathbf{3 0}$ & $\mathbf{1 0 0}$ \\
\hline
\end{tabular}

Before a statistical calculation is carried out, the normality of data testing is done first. The data normality test results to determine whether the data collected from 30 subjects have been distributed normally or abnormally, then the normality of the data is tested using the Saphiro-Wilk test, the data distribution is said to be normal if $p>0.05$. The results of the normality test for halitosis scores before gargling with green tea water have a value of $\mathrm{p}=$ 0.004 and after gargling with green tea water have a value of $p=0.002$. It can be said that the data is distributed abnormally, so the difference test used a non-parametric test, ie Wilcoxon test.

The results of the non-parametric Wilcoxon test showed halitosis scores before and after gargling with green tea water had a value of $p=0.000$. Because $p<0.01$, it can be concluded 
that there were a significant differences between halitosis scores before and after gargling with green tea water.

Table 3. Frequency of halitosis scores before treatment (with cinnamon).

\begin{tabular}{clcc}
\hline Scores & Halitosis & Frequency & \% \\
\hline 0 & No Odor & 0 & 0 \\
1 & Slight Odor & 0 & 0 \\
2 & Moderate Odor & 10 & 33 \\
3 & Heavy Odor & 11 & 37 \\
4 & Strong Odor & 6 & 20 \\
5 & Intense Odor & 3 & 10 \\
\hline Total & & $\mathbf{3 0}$ & $\mathbf{1 0 0}$ \\
\hline
\end{tabular}

Table 4. Frequency of halitosis scores after treatment (with cinnamon).

\begin{tabular}{clcr}
\hline Scores & Halitosis & Frequency & \% \\
\hline 0 & No Odor & 0 & 0 \\
1 & Slight Odor & 15 & 50 \\
2 & Moderate Odor & 8 & 26 \\
3 & Heavy Odor & 5 & 17 \\
4 & Strong Odor & 2 & 7 \\
5 & Intense Odor & 0 & 0 \\
\hline Total & & $\mathbf{3 0}$ & $\mathbf{1 0 0}$ \\
\hline
\end{tabular}

The results of the non-parametric Wilcoxon test showed halitosis scores before and after gargling with green tea water had a value of $p=0.000$, because $p<0.01$, it can be concluded that there were a significant differences between halitosis scores before and after gargling with cinnamon decoction.

Table 5. The Differences of the Mean Halitosis Scores in Green Tea Water and Cinnamon Decoction.

\begin{tabular}{lccc}
\hline & Mean & SD & Pvalue \\
\hline Green tea water & 2.4 & 0.855 & $0.017^{*}$ \\
Cinnamon decoction & 1.8 & 0.961 & \\
\hline
\end{tabular}

*pvalue $\leq 0.05$, CI 95\%,paired t-test

Table 5 showed that there were differences in halitosis scores in green tea water and cinnamon decoction. The mean halitosis score in green tea is higher than cinnamon, which means cinnamon decoction is more effective in lowering halitosis scores compared to green tea water.

\section{Discussion}

The benefits of tea are derived from the chemical compounds contained in tea leaves. Chemical compounds in tea leaves consist of phenol substances, non phenols substances, aroma substances, and enzymes. The four groups of chemical compounds together support the properties of tea when tea processing is done properly. Catechins are the compounds most 
responsible for causing healthful effects from tea. Green tea is a type of tea that has a very high catechins content [5].

The catechins contained in green tea are believed to reduce dental plaque formation through two mechanisms, by killing causative bacteria such as Streptococcus mutans, and inhibiting bacterial glycosyltransferase enzyme activity [6]. Catechins are compounds contained in tea that can inhibit the growth of bacteria which cause halitosis [7].

Research conducted on Santriwan/Santriwati at Pesantren Khusus Yatim As-Syafi'iyah intends to continue the research conducted by Shinta Sartika L, Shirley ES Kawengian, and Ni Wayan Mariati in 2015 about the effectiveness of gargling with green tea water in reducing accumulation of plaque [8]. Results from the research on Santriwan/Santriwati at Pesantren Khusus Yatim As-Syafi'iyah were in accordance with the study. The study explained that gargling with green tea water was successful in reducing plaque accumulation. Dental plaque is one of the factors that cause halitosis. This is because the content of green tea, catechins, has the ability to reduce the formation of Streptococcus mutans as a component of dental plaque formation, and also the cause of dental caries [9-10].

Research by Reca, Ainun Mardiah, and Cut Nurasakin about the effect of gargling with green tea solution on the plaque index in class VI of SDN 62 Banda Aceh in 2015 showed that there was a decrease in plaque index, before and after gargling with green tea solution. A decrease in plaque index caused by the antibacterial content of green tea that can eliminate toxins and bacteria in the mouth [10].

Research conducted by Fajriani and Sartini Djide on the manufacture of green tea catechins toothpaste and inhibitory tests on Streptococcus mutans in 2015 showed that green tea catechins toothpaste proved to be very effective in inhibiting the activity of cariogenic bacteria This is because the bioactive components of green tea can influence the process of dental caries by inhibiting proliferation, acid production, metabolism and activity of the glucosiltransferase (GTF) from Streptococcus mutans and plaque. It is well known that Streptococcus mutans is a major cause of dental caries and it is one of the factors that cause halitosis [11].

Cinnamon has a spicy and sweet taste, smells good, and it's warm. The properties possessed by the cinnamon come from the chemical compounds contained in cinnamon essential oil. Some of the chemical compounds contained in cinnamon essential oil consist of groups of phenol, eugenol, cinnamaldehyde and tannins. Cinnamon is very effective as an antioxidant, antiulser, antimicrobial, antidiabetic and anti-inflammatory effects and has traditionally been used to treat toothache and overcome bad breath (halitosis) [12-13].

Cinnamaldehyde and eugenol besides being the main ingredients in cinnamon, these compounds also cause healthy effects for the body [14]. Eugenol has antibacterial properties, even when diluted more than 2000 times. Hydrophobicity of eugenol is an important factor that influences antibacterial activity [15]. Cinnamaldehyde is an aromatic aldehyde that has an antifungal effect [16-17].

Based on a research conducted by Marisya Ardani, Sylvia Utami Tunjung Pratiwi and Triana Hertiani about the effects of clove leaves and cinnamon cortex essential oils blend as an anti plaque in 2010, it was found that clove and cinnamon essential oils contained phenylpropanoid compounds (such as eugenol and cinnamaldehyde). These compounds can accumulate in bacterial cell membrane lipids and cause disruption of the structure and function of cell membranes caused by cell membrane expansion and changes in permeability of bacterial cell membranes. The bled of clove and cinnamon essential oils had proven to be very effective in inhibiting the activity of Streptococcus mutans. It is known that Streptococcus 
mutans plays a dominant role in the formation of dental plaque, dental caries, and one of the factors that causing halitosis [18].

Research about rinsing with green tea water and cinnamon decoction against halitosis had showed a good results. Gargling with both ingredients proved to be able to reduce the halitosis score. The research hypothesis was proven, because it appears that there were a significant differences between the initial and final halitosis scores in subjects. Through this research, it appears that the effect of gargling with cinnamon decoction on halitosis at Pesantren Khusus Yatim As-Syafi'iyah showed a significant results. It has been proven that gargling with cinnamon decoction can reduce the halitosis score. This is due to the content of eugenol and cinnamaldehyde which found in cinnamon. Rinsing with cinnamon decoction is more effective in lowering halitosis scores compared to green tea.

\section{Conclusion}

Based on the results of the study on the effect of gargling with green tea water and cinnamon decoction on halitosis at Pesantren Khusus Yatim As-Syafi'iyah, it can be concluded that there were a decrease in halitosis scores after gargling with green tea water and cinnamon decoction. Decreasing halitosis scores after gargling with green tea water is caused by the content of green tea, a catechin which has an antimicrobial properties. Decreasing halitosis scores after gargling with cinnamon decoction is due to the content of eugenol and cinnamaldehyde. The mean halitosis score in green tea is higher than cinnamon, which means cinnamon decoction is more effective in lowering halitosis scores compared to green tea water.

\section{References}

[1] Wiyatmi, H.: Penyebab Halitosis dan Penanganannya di Rumah Sakit Jiwa Grhasia Propinsi DIY. Available in http://grhasia.jogjaprov.go.id/images/grhasia/pdf. (Accessed on April 22 $2^{\text {nd }}$ 2017).

[2] Jiun ILE, Siddik SNAB, Malik SN, Tin Oo MM, Alam MK, Khan MMH.: Association between oral hygiene status and halitosis among smokers and nonsmokers. Oral Health and Preventive Dentistry, 13(5) pp 1-11 (2015).

[3] Yuwono, LF.: Daya Antibakteri Ekstrak Daun Teh (Camellia sinsesis) terhadap Pertumbuhan Strepcoccus sp pada Plak Gigi. Skripsi Penelitian Mahasiswa (2009).

[4] Jakhetia V, Patel R, Khatri P, Pahuja N, Garg S, Pandey A, Sharma S, et al.: Cinnamon: A Pharmacological Review. Journal of Advanced Scientific Research, 1(2) pp 19-23 (2010).

[5] Towaha J, Balittri.: Kandungan Senyawa Kimia pada Daun Teh (Camellia sinsesis). Warta Penelitian dan Pengembangan Tanaman Industri, 19(3) (2013).

[6] Muin AI, dan Munandar S.: Pengaruh Pemberian Teh Hijau (Camellia sinsesis) terhadap Pembentukan Plak Gigi. Media Medika Muda Semarang: Universitas Diponegoro. Available in http://eprints.undip.ac.id/1489///artikel_01.htm. (2006).

[7] Mokeem, SA.: Halitosis: A Review of the Etiologic Factors and Association with Systemic Conditions and its Management. JCDP, pp 806-811 (2014).

[8] Sartika SL, Kawengian SES, Mariati NW.: Efektivitas Berkumur dengan Air Seduhan Teh Hijau dalam Menurunkan Akumulasi Plak. Jurnal e-GiGi (eG), 3(2) pp 426-431 (2015).

[9] Damayanthi E, Kusharto MC, Suprihatini R.: Studi Kandungan Katekin dan Turunannya sebagai Antioksidan Alami serta Karakteristik Organoleptik Produk Teh Murbei dan Teh Camellia-Murbei. Media Gizi dan Keluarga, 32(1) pp 95-103 (2008).

[10] Reca R, Mardiah A, Narasakin CA.: Pengaruh Berkumur dengan Larutan Teh Hijau terhadap Index Plak pada Murid Kelas VI SDN 62 Banda Aceh. SEL Jurnal Penelitian Kesehatan, 2(2), pp 66-71 (2015). 
[11] Fajriani F, Djide S.: Pembuatan Pasta Gigi Katekin Teh Hijau dan Uji Daya Hambat terhadap Bakteri Streptococcus mutans dan Lactobascillus ascidophillus. Majalah Kedokteran Gigi Indonesia, 1(1), pp 27-31 (2015).

[12] Nurmalasari DL, Damiyanti M, Eriwati YK.: Pengaruh Larutan Ekstrak Kayu Manis Terhadap Kekasaran Permukaan Email Gigi Manusia. (Accessed on April $1^{\text {st }}$ 2017), available in http://lib.ui.ac.id/naskahringkas/ 2015-08/S-Dita\%20Liesdi\%20Nurmalisari. (2015).

[13] Islami U 2014 Kayu Manis (Cinnamomum burmannii). (Accessed on April 18 ${ }^{\text {th }}$ 2017), available in https://www.scribd.com/doc/243637695/ isi-makalah-kayu-manis-docx.

[14] Inna M, Atmania N, Prismasari S.: Potential Use of Cinnamomum Burmanii Essential OilBased Chewing Gum As Oral Antibiofilm Agent. Journal of Dentistry Indonesia, 17(3) pp 8086 (2010).

[15] Repi NB, Mambo C, Wuisan J.: Uji Efek Antibakteri Ekstrak Kulit Kayu Manis (Cinnamomum Burmanii) terhadap Escherichia coli dan Streptococcus pyogenes. Jurnal e-Biomedik (eBM), 4(1) pp 1-5 (2016).

[16] Dama C, Soelioangan S, Tumewu E.: Pengaruh Perendaman Plat Resin Akrilik Dalam Ekstrak Kayu Manis (Cinnamomum burmanii) terhadap Jumlah Blastospora Candida albicans. Jurnal e-Gigi, 1(2) pp 1-5 (2013).

[17] Erna F, Rostiny, Salim S.: Efektivitas Minyak Kayu Manis dalam Menghambat Pertumbuhan Koloni Candida albicans pada Resin Akrilik. Journal of Prosthodontics, 1(2) pp 19-23 (2010).

[18] Ardani M, Pratiwi SUT, Hertiani T.: Effect of Clove Leaves and Cinnamon Cortex Essential Oils Blend as Anti Dental Plaque. Majalah Farmasi Indonesia, 21(3). Pp191-201 (2010). 